\title{
The pre-history of the incarnation of Jesus Christ in the Christology of T.F. Torrance
}

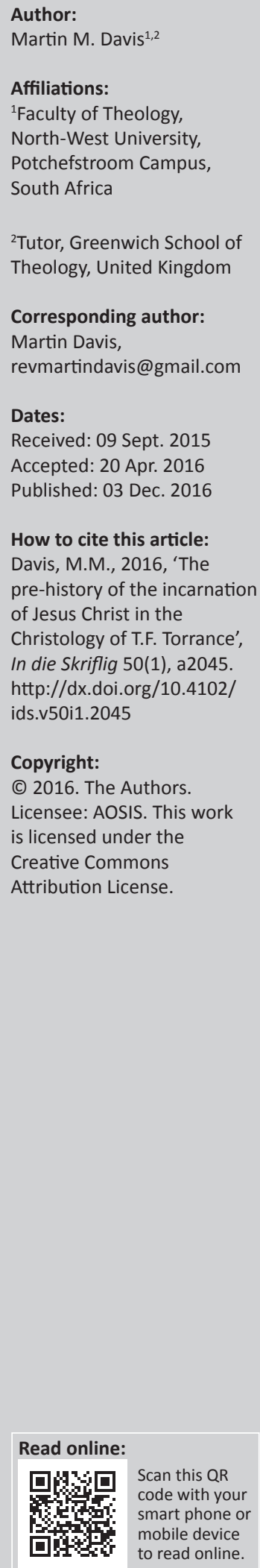

T.F. Torrance is widely known for his dialogue between theology and the natural sciences. His Christology, however, merits greater attention in the academic literature, particularly in regard to his important discussion of the prehistory of Jesus Christ's incarnation in the nation of Israel. The purpose of this article is to address this inadequacy. The present article provides an overview of Torrance's discussion of the mediation of revelation and reconciliation in Israel and relates it to Jesus Christ's incarnation. Content is based on a review of the primary literature published over a span of more than 40 years, as well as a review of the relatively few secondary resources that include an extensive discussion of this subject matter. Torrance's discussion of the prehistory of the incarnation in Israel provides the biblical-historical background for his Christology. For Torrance, divine self-disclosure and human response in the context of God's covenant interaction with Israel constitute a two-fold but unitary movement of mediation in Israel that is ultimately embodied and enacted in the person and life of Jesus Christ. As Torrance argues, Jesus Christ incorporates in his incarnate person, life, death and resurrection the prehistory of the mediation of revelation and reconciliation in Israel. Torrance's discussion of the prehistory of the incarnation in Israel provides a helpful hermeneutical framework for understanding the purpose, meaning and goal of God's covenant interaction with Old Testament Israel as a preparation for the advent of Jesus Christ.

\section{Introduction}

According to McGrath (1999:xi) and Molnar (2009:1), Thomas F. Torrance (1913-2007) is widely regarded as one of the most important British academic theologian of the 20th century. Colyer (2001:15) notes that many regard Torrance as the most outstanding reformed theologian in the Anglo-Saxon world. Torrance is especially noted for his contribution to the study of the relationship between Christian theology and the natural sciences (Colyer 2001:15; McGrath 1999:xi).

One aspect of Torrance's thought that has received insufficient attention in the academic literature, however, is his articulation of the nation of Israel's role in relation to the incarnation of Jesus Christ. ${ }^{1}$ In view of this inadequacy, this article will provide an overview of Torrance's discussion of the meditation of revelation and reconciliation in Israel, examining the purpose, meaning and goal of God's covenant interaction with Israel in relation to Jesus Christ's incarnation.

\section{The epistemological linchpin}

In regard to the knowledge of God, in general, and the mediation of Christ, in particular, Torrance adopts a critical realist epistemology (McGrath 1999:217). Critical realism takes note of human perception's role in the process of knowing, but not to the extent that belief in the independent reality of the object of knowledge is diminished. Torrance's critical realist theology $(1990: 52,53)$ takes as its fundamental proposition that God 'is'; that is to say, God has a reality independent of our knowledge of him, a reality made known to us concretely and historically in Jesus Christ. Like Calvin and Barth, Torrance adopts an actualist position toward divine revelation, that is, he does not begin with the possibility of revelation but with its actuality. Torrance's theology is nonfoundationalist; it is grounded in how God has revealed himself, not on speculation as to how God might reveal himself (Purves 2015:26, 29, 30). Torrance stringently adheres to the scientific theological approach of the Patristic era, wherein theological knowledge was developed according to the nature (kata physin) of the object of inquiry. The Patristic approach to knowledge of God is succinctly captured in the statement 'only through God can God be known', often quoted by Torrance (1983:8ff.; 1988:54; 1996a:77). For Torrance, God's being is revealed in his act (Habets 1.Treatment of this subject is found in Kruger (1989), Colyer (2001), Scandrett (2006) and Chung (2011).

Note: Some of the writing and research of this article is based on work previously published by the author. Please see link: http:// martinmdavis.blogspot.co.za/ 
2013:32-35). Torrance finds this doctrine clearly articulated first by Athanasius and, in modern times, by Karl Barth.

For Torrance (1969:110-113; 1988:3, 51, 52), Jesus Christ's incarnation is the controlling centre of the Christian doctrine of God. To know God through the incarnate Son who is 'of one substance with the Father' (homoousios to Patri), is to know God in strict accordance with God's nature and, hence, in a theologically scientific way. For Torrance (1980:160, 161; 1988:110ff.; 1996a:30; 1996b:128), the Nicene homoousion is the epistemological and ontological linchpin of revelation and reconciliation, and therefore of the entire enterprise of a Christian scientific theology. As Eugenio (2014:31) observes, Torrance's argument for a proper understanding of the identity of Christ as homoousios to patri is extremely relevant for contemporary theology, particularly in view of the Arianism of recent centuries.

\section{The mediation of revelation in Israel}

The incarnation of Jesus Christ did not occur in an epistemological vacuum. Torrance (2008:37) refers to a 'prehistory' to the incarnation in Israel, that is, a significant background of preparation and significance that must not be overlooked. ${ }^{2}$ According to Torrance $(1992: 3,23)$, the incarnation of Jesus Christ must not be detached from its deep roots in the covenant between God and Israel. If we are to know Jesus Christ, we must seek to understand him within the actual matrix of interrelations from which he sprang, that is, in terms of his intimate bond with Israel in its covenant relationship with God.

For Torrance (1982:85), revelation is not a vague, inarticulate awareness that arises from human consciousness. Rather, it is an intelligible revealing of God by God that we are enabled to apprehend by the power of God's word addressing us within the medium of human thought and speech. If we are to know God and speak of him in appropriate ways, Torrance (1992:6; 2008:41) argues, we must have fitting modes of thought and speech, and reverent and worthy worship habits in approaching God. Just as a workman needs appropriate tools to complete his task, we need conceptual tools to understand God, that is, basic categories, concepts, and beliefs that enable us to receive and assimilate divine revelation within the comparatively limited capacity of human understanding.

Torrance $(1952: 164,165 ; 1992: 6,7 ; 2008: 40,41)$ notes that, in order to develop the appropriate conceptual tools for divine revelation, God chose Israel and subjected it to intense interaction with himself in order to mould and shape the nation for the purpose of divine revelation. For the sake of the entire world, God gave Israel a set of spiritual tools and appropriate forms of understanding, worship and expression so that knowledge of God could be revealed in a means amenable to human understanding. The forms of speech and thought that God gave Israel are not arbitrary. In other words, it is not merely human speech or concepts as such that Torrance has in view. Rather, Torrance is concerned with ways of human knowing and worship that are appropriate to God (Kruger 1989:47; Scandrett 2006:35).

\section{A community of reciprocity}

In order for divine revelation to enter history in a form amenable to human understanding, Torrance (1971:146, 147; $1982: 85,86)$ argues that it must arise within the context of community. Language is the currency of social being, rooted in society and kept alive by the interchange of ideas within it. Thus, 'word' or language does not develop in isolation, but within a community of persons bound by a common way of life. Therefore, for divine revelation to create a reciprocity between God and humanity, it must create a community of reciprocity as the appropriate medium for divine communication. This happened in Israel, where the Word of God penetrated the particular life and history of one people elected as the instrument of divine revelation to humanity.

According to Torrance (1992:7), the self-revelation of God in Israel in the medium of human thought and speech requires a two-way movement: 'an adaptation of divine revelation to the human mind and an adaptation of articulate forms of human understanding and language to divine revelation'. Torrance (1996b) notes that the two-way movement of divine revelation and human response is integral to Old Testament thought, wherein:

revelation is not only the uncovering of God but the uncovering of the ear and eye of man for God. It is revelation which achieves its end in man and does not return void to God. (p. 130)

In contrast to Kantian epistemological dualism, Torrance (1969:45) regards 'knowing' as a reciprocal dynamic between knower and known. The mediation of divine revelation requires both a movement from God to humanity and a responsive movement from humanity to God. In establishing a covenant relationship with Israel, God graciously adopted a way to make himself known in which the movement of revelation fulfilled itself, not only from the side of God toward man, but also from the side of man toward God (Torrance 1992:22). Divine revelation was progressively mediated to humanity through Israel in such a way as to make the appropriate human response a constitutive aspect of the mediation of revelation. Torrance is not merely describing a divine revelation that demands a human response. Rather, and most significantly, he is describing a divine revelation that already includes an appropriate response that is an essential aspect of revelation. For Torrance, divine revelation and appropriate human response taken together constitute the mediation of revelation in Israel. In an essay on Christology, Torrance (1996b) writes:

Revelation involves the freedom of God to be present to man and to open up man for God and to realize from the side of man his understanding of revelation and his obedient response to it, to effect in man real meeting with God in revelation and to give him capacity for revelation. (p. 131)

Torrance's assertion that God 'opens up man' to receive divine self-disclosure is consistent with a primary tenant of 
his scientific theology, viz. rational knowledge arises only in obedient response to the nature ((kata physin) of the object of inquiry (Torrance 1969:viii; 1971:92; 1992:25). As Chung (2011:10) notes, although the relationship between the divine and human aspects of mediation in Israel is asymmetrical, human participation, however insignificant in comparison to divine grace, constitutes an indispensable place in the mediation of revelation.

Torrance's discussion of the two-way movement of divine revelation and human participative response in Israel is highly relevant to his Christology. Following Athanasius, ${ }^{3}$ Torrance describes a two-fold ministry in which Jesus ministers the things of God to man and the things of man to God. This two-fold ministry constitutes an indivisible whole in the union of divine and human natures in the incarnate Son that is continuous throughout his life, death, resurrection and ascension (Torrance 1992:73). ${ }^{4}$

In terms of epistemology, Torrance's description of the reciprocal movement of divine revelation and human response in Israel is consistent with his larger conception of the rational order of creation, for the eternal Word that created the world was at work, creating a corporate reciprocity in Israel (Torrance 1971:147). Because God upholds and sustains creation, its rationality is subject to human discovery. God's gracious self-disclosure through the intelligible structures of the universe is ultimately revealed in Jesus Christ's incarnation. As the eternal Logos, who imbued creation with its intelligible structures, the incarnate Son of God embodies the rational order of creation and is the supreme expression of the rational love of God (Torrance 1981a:23, 24).

Moreover, the two-way movement of revelation and response that Torrance finds in Israel is solely a movement of grace. With regard to knowledge of God, Torrance stresses the importance of the doctrine of creation ex nihilo. A fundamental aspect of this doctrine is the contingent nature of creation, that is, the universe is wholly dependent upon God for its origin, existence and order. The contingent nature of the universe means that it contains no self-explanatory logic as to why it came into existence or why it should continue to exist (Torrance 1981a:vii, viii; 1988:95-102). Torrance follows his mentor, Karl Barth, in rejecting the medieval assertion of a logical bridge (analogia entis) between God and the world that would allow knowledge of God to be abstracted and developed independently from the incarnation (Torrance 1970:126; 1996b:26). For Torrance, we know God, because he graciously gives himself to be known in Jesus Christ.

\section{Intensification of conflict}

In an 'ever-deepening, spiral movement' of divine revelation, Israel underwent a painful process wherein it was repeatedly broken upon the wheel of divine providence in order to

3.Athanasius, Contra Arianos 1:41ff, $50 \mathrm{ff} ; 11.7 \mathrm{ff}, 12 \mathrm{ff}$

4.For a recent overview of Torrance's Christology, see Davis (2013). become pliable in the service of God's self-communication (Torrance (1992:7-9). Divine revelation steadily burned away false concepts of divinity ingrained in the fallen human mind and facilitated the development of patterns of thought and speech worthy of God. As a community entrusted with the oracles of God, Israel became an oddity among the nations, as the Word of God prepared the matrix for the mediation of divine revelation so that humanity could receive the personal self-communication of God in the incarnation of Jesus Christ.

As Torrance $(1992: 10,11 ; 2008: 41,42)$ notes, Israel was not chosen to be the mediator of revelation because of any special religious or moral qualities it possessed. Rather, Israel was a stiff-necked people brought into an intense and intimate relationship with God unprecedented among the nations. As God and his people drew closer, the innate resistance of the human mind resulting from humanity's alienation from God intensified so that Israel's rebellion appears to have been in inverse proportion to the grace bestowed upon it. As the holy, righteous and loving character of God was brought to bear upon Israel's mind and thought in the law and liturgy of the covenant, Israel vacillated back and forth between worship of the true God and idolatry. Refusing to allow his redemptive purpose for humanity to be thwarted, God broke Israel time and again like a clay pot on the potter's wheel. As Scandrett $(2006: 45,50)$ notes, the people of Israel were trapped in an intensifying cycle of suffering, caught between the ever-deepening spiral movement of God's will to reveal himself and their own will to resist that revelation. For Torrance, this agonised relationship is neither accidental nor incidental, but establishes the basic form for understanding the reconciling work of God in human history (Scandrett 2006:50).

\section{The essential furniture of the knowledge of God}

In hammering out his self-revelation on the anvil of Israel, Torrance $(1952: 165,166 ; 1992: 18,19 ; 2008: 42)$ notes that God crafted the 'essential furniture' of our knowledge of him so that we may know Jesus as Son of God and Saviour of the world. Through centuries of existence yoked to his word and covenant, God brought his people to the brink of the Gospel, teaching them the meaning of holiness and righteousness, love and mercy, sin and uncleanness, justification, atonement and salvation as well as the concepts of Messiah, Suffering Servant, prophet, priest and king.

In revealing himself to Israel, God did not simply provide a list of statements about himself, for this would be interpreted in light of a prior communal meaning rooted in naturalistic and pagan preconceptions that obstructed knowledge of God (Torrance 1971:147, 148). Rather than a theology of God, Israel would inevitably create what Torrance (1988:73) calls 'mythology', viz. thinking of God from a centre in the human mind and its fantasies. Rather than the projection of mythological ideas onto the heavens, the mediation of true knowledge of God required the critical revision of old thoughts forms in favour of new forms of worship, thought and expression (Torrance 1971:147, 148). 
According to Torrance (1992:22), the mediation of revelation in Israel inevitably pointed ahead to the incarnation. The prehistory of the mediation of revelation was brought to its consummation in Jesus Christ in such a way that transient, time-conditioned elements fell away, while basic, permanent ingredients in God's revelation to Israel were incorporated into the intelligible framework of God's full and final selfdisclosure in the incarnation. Within the matrix of his interrelations with Israel, Jesus Christ stands forth as the controlling centre of the personal self-revelation of God. Nevertheless, though it is Jesus Christ, not Israel that constitutes the personal self-revelation of God, it is Jesus Christ in Israel and not apart from Israel that constitutes the reality and substance of divine self-disclosure (Torrance 1992:23). Because Jesus Christ must be viewed in the nexus of his interrelations with God's people, Israel is included forever within God's chosen way of self-disclosure to the world. Because Israel is given a permanent place in the mediation of revelation, the Old Testament must be understood in light of its fulfilment in Christ, while Jesus, in turn, must be viewed in the normative framework of basic preconceptions divinely provided in the Old Testament. Torrance (2008):

Apart from the context of Israel, we would not even begin to understand the bewildering enigma of Jesus. The supreme instrument of God for the salvation of the world is Israel, and out of the womb of Israel, Jesus, the Jew from Nazareth. (p. 44)

\section{The mediation of reconciliation in Israel}

God's election of Israel as mediator of reconciliation must be viewed against the background of God's eternal purpose in creation. According to Torrance (1957:190), God created the universe in order to pour out his love in covenant partnership with humanity. Notwithstanding the fall of Adam, God's resolute purpose is undeterred by human sin. Torrance (1957) writes:

$[I] \mathrm{n}$ creating man God willed to share His glory with man and willed man to have communion with Himself; it is the fact of the overflowing love of God that refused, so to speak, to be pent up within God, but insisted in creating a fellowship into which it could pour itself out in unending grace. Far from being rebuffed by the disobedience and rebellion of man, the will of God's love to seek and create fellowship with man established the covenant of grace ... in the midst of the people of Israel, and all through their history God was patiently at work, preparing a way for the Incarnation of His love at last in Jesus Christ, that in and through Him He might bring His covenant to complete fulfilment and gather man back into joyful communion with Himself. (p. 190)

In arguing that God's love refused to be 'pent up', but rather 'insisted in creating a fellowship' into which God could pour out his love, Torrance may appear to come dangerously close to suggesting that creation is necessary to God. Like Barth (1958:95), however, Torrance (1981a:vii) does not regard creation as necessary. For Torrance (1988:89), God is who he is in himself, independent of creation and entirely unconditioned by any reality other than himself. Torrance (1988:90) asserts that 'God is transcendently free and in need of nothing beyond himself ... for as Father, Son and Holy Spirit, he is an eternal communion of love and personal being in himself.' As an eternal communion of love, God creates not from need, but from his gracious will to share his love with creation.

For Torrance the covenant of grace is intrinsically bound to creation. In contrast to an imaginary inherent relation of likeness and being between God and the world (i.e. analogia entis), Torrance describes a covenanted correspondence between the Creator and creation. God graciously assumes creation into relation with himself so that he may use it as 'the instrument of His glory, and as the sphere in which $\mathrm{He}$ creates fellowship between man and Himself' (Torrance 1959:li). Like Barth (1958:94ff.), Torrance (1959:li, lii) describes the Covenant as 'the inner ground' and form of the creation, and creation as 'the outer ground' and form of the Covenant. Torrance refers to the covenant of grace established at creation as 'the one all-embracing Covenant of the overflowing love of God'. At the centre of the Covenant is the will of God to be our Father and to have us as his children. Creation is the sphere in space and time in which God wills to share his life and love with humanity which is created for this purpose.

In light of human sin, Torrance (1971:141) notes that God's creative plan takes on a redemptive purpose with the calling of Abraham. God chose Israel, the children of Abraham, not only as the medium of divine revelation in space-time history, but also as the medium of his redemptive acts leading throughout history to the fulfilment of his promise of salvation. The mediation of revelation and the mediation of reconciliation are intertwined in God's interaction with Israel (Torrance 1996b:194). For Torrance (1992:24), ‘[R]evelation and reconciliation belong together, so that we cannot think out the mediation of revelation apart from the mediation of reconciliation.'

\section{Divine holiness and communal transformation}

Torrance $(1992: 25,26)$ insists that the knowledge of God must be developed within a context of faith and godliness, wherein love and obedience belong inseparably together. For Torrance, there is no 'head-heart' dualism. In other words, we cannot know God without love, for knowing God requires cognitive union with him in such a way that our whole being is affected by his love and holiness. In harmony with a fundamental principle of his scientific theology, wherein epistemology follows ontology, Torrance insists that it is the pure in heart who see God.

Torrance $(1992: 15,26,27)$ finds this principle at work in Israel, where the unconditional self-giving of God required an unconditional response on the part of Israel. ${ }^{5}$ By entering relations of holiness with God, the character of Israel's existence as God's chosen people was affected in distinctive and idiosyncratic ways. Rather than engage Israel merely at the surface of its moral and religious consciousness, 5.'You shall be holy, for I the LORD your God am holy' (Lv 19:2). 
the searing light of divine revelation penetrated deep into the depths of Israel's existence in order to transform the corporate mind and heart of the nation. As Chung $(2011: 6,8)$ argues, revelation was not merely a business of cognition; it had to affect the entire corporate life of the nation. Otherwise, the people's innate weakness would have eclipsed the revelation of God and prevented the fulfilment of their role as the corporate medium of divine revelation and reconciliation.

\section{The covenanted way of response}

In electing Israel to be his covenant partner, Torrance $(1992: 27,28,74)$ argues that God knew the people would not be able to fulfil the provisions of the covenant by walking before God in perfect holiness. Nor would Israel be able to worship God in an appropriate way, for the covenant between God and Israel was one of grace between God and a sinful people. The validity of the covenant, however, did not depend on a contractual fulfilment of its terms on the part of Israel. Rather, the covenant was unilateral, depending solely for its fulfilment on the unconditional grace of God and the unrelenting purpose of reconciliation that God pledged to effect through Israel for all people. God's covenant commitment to his people was both prior to and unconditioned by any appropriate response on the part of Israel, that is, God's covenant commitment was an act of pure grace.

Torrance $(1992: 73,74)$ notes that, in his love and mercy, God provided the means whereby weak and beggarly Israel could respond to his love so that the liturgy of atonement might be incorporated into the life of the people. God provided Israel a middle term between the polarities of the covenant (i.e. God and humanity), viz. a 'covenanted way of response' that allowed the people to respond in a vicarious way to God's grace. God's provision of the appropriate means of response to divine love was a constitutive aspect of the covenant. As Kruger (1989:40, 41) observes, 'God filled Israel's hands with His own provision so that Israel could draw near to God in worship and communion', which means that God provided what he required.

The vicarious means by which Israel was to respond to God was elaborated in the ordinances of worship described in the Pentateuch in which the people were forbidden to bring offerings 'embodying their own self-expression or representing their own naturalistic desires, or with kinds of sacrifices thought up by themselves as means of expiating guilt or propitiating God' (Torrance 1992:74, 75). God's gracious provision of the covenanted way of response included judgement on human offerings by rendering them unworthy and redundant. The cultic liturgy was designed to witness to the fact that only God can expiate guilt, forgive sin and bring about propitiation between himself and his people. The sacrifices, offerings and oblations as well as the priesthood itself, constituted the vicarious way of covenant response in faith, obedience and worship that God, in his steadfast love, graciously provided to his people.
Torrance (1992:89-91) sees a parallel between the visible signs of the cultic liturgy in Israel and the sacraments of the Christian church. As a Protestant theologian, Torrance acknowledges the sacraments of baptism and the Eucharist. While these are acts of human response to the proclamation of the Gospel, Torrance contends that they are divinely provided ways of response of a radically vicarious kind. Just as Israel was not allowed to come before God with offerings and sacrifices of their own choosing, also in the new covenant, appropriate forms of human response are vicariously provided in Jesus Christ. The sacraments replace the rites of circumcision and Passover in consequence of the fundamental change in the covenant relation between God and his people effected in the incarnation and atonement. As visible signs, the sacraments direct us away from ourselves to our Lord and Saviour.

Torrance's discussion of the mediation of reconciliation emphasises the gracious, unilateral and vicarious nature of the covenanted way of response that God provided Israel so that a sinful nation could approach a holy God in appropriate and reverent worship. These essential aspects of the mediation of reconciliation in Israel bear directly on the mediation of Jesus Christ. According to Torrance (1992:73ff.), the vicarious way of covenant response God provided Israel is finally and fully realised and faithfully enacted in the incarnation. As both God and man united in reconciling union, as both Lamb of God and High Priest, Jesus fulfils both sides of the covenant in his incarnate person. Jesus is both the revelation of God and the answering response to divine self-disclosure.

\section{Intensification of the covenant}

As God drew nearer to Israel in the act of reconciling love, Israel's sin was not only revealed, but also intensified. As Torrance (1992:28, 29; 2008:47-52) notes, this was not an accidental feature of the covenant. Rather, the intensification of Israel's sin was incorporated into the full design of the covenant, for it was God's will to effect reconciliation with humanity at its worst, that is, in a state of stiff-necked rebellion against God. Torrance (1992:11) refers to the intensification of Israel's enmity against God in the face of divine revelation as the 'pre-history [sic] of the crucifixion and resurrection of Jesus in Israel'.

According to Torrance (1992:32, 33), Israel was called to be the 'covenanted vis-à-vis' on earth in the movement of God's reconciling love for all humanity. Even in the face of Israel's rejection, God bound himself to the people in love so that Israel was unable to escape its covenant partnership with God. Torrance asserts that human resistance and estrangement were incorporated into God's gracious plan for the reconciliation of humankind. He illustrates this point by describing the events after the Last Supper, when, in fear of their lives, the disciples denied and abandoned Jesus when he was arrested by the authorities. In enacting the new 
covenant for the remission of sins by giving them his body and blood in the bread and wine of the Holy Supper, Jesus meant the disciples to understand that even their denial of him was the means by which he bound them to himself in love.

As Torrance argues, the disciples finally realised that Jesus' passion was not for the holy saint, but for the sinner. $\mathrm{He}$ (Torrance 1992) notes that:

It was their sin, their betrayal, their shame, their unworthiness, which became in the inexplicable love of God the material he laid hold of and turned into the bond that bound them to the crucified Messiah, to the salvation and love of God forever. (p. 34)

For Torrance, this is surely how we must understand God's election of Israel to be the bearer of divine revelation and reconciliation despite their recalcitrance and rebellion. Urging that we clap our hands over our mouths and speak with fear and trembling within the forgiving love of God, Torrance (1992) asserts that Israel was elected to reject the Messiah:

If the covenant partnership of Israel with God meant not only that the conflict of Israel with God became intensified but was carried to its supreme point in the fulfilment of the Covenant, then Israel under God could do no other than refuse the Messiah. (p. 34)

Against possible charges of anti-Semitism, Torrance is not suggesting that God made the Jews guiltier than others in electing them to reject the Messiah. Rather, Torrance (2008:53) writes, 'Israel was elected to act in a representative capacity for all peoples in its rejection of Christ.' A stubborn opponent of anti-Semitism (Purves 2015:62), Torrance $(1992: 11,12)$ traces the roots of anti-Semitism to humanity's enmity against God. The history of Israel shows that divine revelation not only discloses the nature of God, but also the nature of human enmity against God. Since God used Israel to mediate divine revelation, our resentment against God is easily projected onto the Jews. As Torrance (1992:11) argues, 'while our real quarrel is with the searching light of divine revelation as reflected by Israel, it is against Israel itself that we vent our resentment'. Through Israel, God exposed humanity's hatred of grace, drawing it out at the cross in all its intensity (Torrance 2008:53). Jesus bore the guilt, not only of Israel, but of all humanity revealed in the guilt of Israel, and thereby acquitting and justifying Jew and Gentile alike. As Peter announced at Pentecost (Ac 2:23), the rejection of the Messiah was exactly what God intended in his determination to deal with sinful humanity at its worst, even at the point of its ultimate denial of the saving will of God. As Torrance $(1992: 34,35 ; 2008: 49,50)$ argues, if Israel was blinded in its role as the servant of God (Is 42:19), and, hence, could not help but react as it did, it was blinded for the sake of all humanity. The Jews vicariously represent our own rejection of God so that reconciliation might also be ours. We are all indebted to the Jews, because their rejection of the Messiah is the means God used to redeem humanity on the cross of Christ.
Moreover, for Torrance (1992:35-39) the role of Israel in the mediation of reconciliation did not end at the cross. He draws upon the imagery of the Day of Atonement ( $\mathrm{Lv} 16)$ to contrast the roles of the Christian church and the 'Jewish church' or synagogue after the crucifixion and resurrection. Both churches bear witness to the nature of the atonement in obverse but mutually supportive ways. After Christ's death and resurrection, the Christian church, representing Christ's finished work, moves forward into history as the church of the Lamb that was slain, but is forever triumphantly alive. The Jewish church, on the other hand, moves forward under the shadow of the cross as the church of the scapegoat, cast out and scattered among the ghettos of the earth. As God's chosen people, the Jews continue to bear and suffer from humanity's scorn and rejection of God and thereby prolonging the atonement forward in time. Nevertheless, God remains faithful to his covenant with Israel (Torrance 2008:54, 55). Just as the rejection of Jesus means his taking our place in order to restore us to life in the resurrection, Israel's rejection of Jesus in our place will mean its restoration to life in the consummation of all things.

Referring to the death of six million Jews in Europe as a burnt-offering laden with the guilt of humanity, Torrance (1992:38) argues that the Holocaust has begun to open Christians' eyes to a new appreciation of Israel's vicarious role in the mediation of redemption. Torrance (1992:38) notes that despite the many theories of the atonement developed in Christian history, we have been unable to grasp the wholeness of the sacrifice of Christ, as it effects both the continuation of God's covenant relationship with Israel and the new covenant in the Body of Christ. Citing the shameful, despicable implication of the Christian West in the Holocaust, Torrance (1992:39) argues that Israel's ongoing role as scapegoat compels us to contemplate aspects of the atonement which we have obscured from ourselves, but may provide the catalyst we need for our understanding of it. The ultimate refusal of God that took place in Israel was the very means by which the loving God achieved final victory over sin, for by the cross, humankind was reconciled to God. Torrance (1992:12) argues that, if we are to be transformed through the renewing of our mind, we must 'go to school' with Israel and share the painful transformation of mind and soul that prepared it for the mediation of revelation in Jesus Christ. As Torrance (1992:35) writes, 'Our indebtedness to the Jew and our faith in Jesus Christ are inextricably woven together in the fulfilled mediation of reconciliation.'

\section{The servant of the Lord}

In the progression of divine revelation, Israel's corporate suffering is gradually associated in the minds of the people with one individual, the Isaianic servant of the Lord, who identifies himself with the nation's plight (Torrance 1992:75, 76 ; 2008:51, 52). The servant of the Lord is the 'hypostasised actualisation', or embodiment of the divinely provided way of covenant response set forth in Israel. In this individual, the mediatorial and priestly figures of Moses and Aaron respectively, and the notions of guilt-bearer and sacrifice for 
sin are conflated to provide the interpretive clue for the representative and substitutionary role of the servant in the redemption of Israel. As Scandrett (2006:55, 56 ) observes, the Isaianic suffering servant brings together the legal and sacrificial dimensions of Israel's life, which together form the two complementary poles of the people's existence as encompassed in the covenanted way of response. The suffering servant acts from within the ontological depths of Israel's sinful existence and, therefore, vicariously, as Israel on behalf of Israel. For Torrance, the Isaianic suffering servant is the penultimate stage of mediation in Israel and reflects Torrance's image of the 'ever-deepening, spiral movement' of divine revelation, as the Old Testament narrows its thrust toward the ultimate goal of the incarnation (Scandrett 2006:56).

For Torrance $(1992: 29,30 ; 2008: 50)$, the incarnation must be understood in this context in which the Son of God gathers up in himself the prehistory of the mediation of reconciliation in Israel and the concomitant intensification of Israel's conflict with God. The suffering and agony of Israel prefigured the suffering of Christ, who embodied and enacted the plight of the suffering servant in order to stand in the gap, in the midst of Israel, on behalf of all humanity. In the death and resurrection of the Messiah, Israel and all humanity were set within the frame of the new covenant of forgiveness and reconciliation through the body and blood of Christ. According to Torrance (1956:309), the Sinaitic covenant becomes new when it is finally cut deep into the heart of Israel's existence, that is, into the inner man. This is precisely what occurs in Jesus Christ. Torrance $(2008: 48,52)$ asserts that the ultimate self-giving of God to Israel, narrowed down in historical particularity to one particular Israelite, means the universalization and transcendence of the Old Testament form of the covenant so that redemption takes on the cosmic dimensions of a new creation.

In view of the cosmic dimensions of Torrance's view of redemption, we must note, before concluding, that Torrance stringently resisted the Reformed doctrine of limited atonement. As Torrance (1992:xiii) notes, however, his attempt to faithfully expound the New Testament teaching that Christ died for all people has been put forth as a doctrine of universal salvation. For Torrance, this implies a logical relation between the death of Christ and the forgiveness of sins. If Jesus died for all, then, logically, all must be saved. Torrance describes this as a rationalist way of thinking that substitutes a logical relationship for the work of the Holy Spirit in accounting for the efficacy of the atonement. Furthermore, Torrance (1949:313; 1996c:277) argues that a doctrine of universalism destroys the free decision of faith by making salvation necessary rather than possible. Thus, universalism can be expressed, at best, only in terms of hope or possibility, but never in terms of dogmatic necessity.

According to Torrance (1981b:136), the construal of a logicocausal relation between grace and human salvation gives rise to the twin errors of limited atonement and universal salvation. Noting that the sacrifice of the lamb on the Day of
Atonement was hidden from view behind the veil in the Most Holy Place, Torrance (1992:xiii, 36) argues that the atonement is to be approached not in the rational terms of logic, but with reverence and awe as a holy mystery grounded in the infinite being of God. For Torrance, the 'why' and 'how' of the atonement remain hidden in the holy love of God.

\section{Summary}

Torrance's approach to knowledge of God may be described as a non-foundationalist, critical realism. For Torrance, scientific theology demands that its object of inquiry be known in accordance with its nature (kata physin) as it unfolds in the process of investigation. To know God through the incarnate Son, who is 'of one being with the Father', is to know God according to his nature, and, hence, in a theologically scientific way. For Torrance, the incarnation is the controlling centre for the Christian doctrine of God.

Torrance (2008:44) argues that, apart from the nexus of its historical interrelations with Israel, Jesus Christ's incarnation would be unintelligible. To set the stage for God's self-disclosure in the incarnation, God called Israel as a community of reciprocity in order to craft the 'essential furniture' of the knowledge of God, that is, basic concepts and images that enable the fallen human mind to receive divine revelation.

God's self-disclosure included an answering movement from Israel as a constitutive ingredient of divine revelation. God graciously provided a system of law and liturgy to enable sinful Israel to engage a holy God in reverent worship. While the covenanted way of response served as a middle ground to bring God and his people together in fellowship, it actually intensified Israel's conflict with God. In order to show his covenant love and faithfulness, even in the face of human recalcitrance at its worst, God elected Israel to reject the Messiah.

The suffering of Israel vis-a-vis its covenant with God is finally associated with a suffering Servant envisioned as the hypostasised actualisation of the divinely provided way of covenant response set forth in Israel. In the fullness of time, Jesus Christ is recognised as the suffering Servant, who, as God and humanity united in his incarnate person, embodies the covenanted way of response, setting Israel and all humanity within the frame of the new covenant of forgiveness and reconciliation.

\section{Critique}

While there are compelling features in Torrance's discussion of the prehistory of the incarnation in Israel, there are also inadequacies. Before proceeding to examine them, however, suffice it to say that Torrance's thinking on the role of the Jewish church in relation to the Christian church warrants further exploration. In associating the Jews with the scapegoat of the Day of Atonement, Torrance offers heuristic insights 
into the post-crucifixion role of Israel in the mediation of reconciliation, particularly with regard to the problem of anti-Semitism. The ongoing role of Israel, particularly in relation to the Christian church, is fertile ground for further development in the field of Torrance studies.

The inadequacies of Torrance's discussion of the prehistory of the incarnation in Israel are related particularly to his description of the divinely provided permanent structures of thought and speech necessary for the mediation of the knowledge of God. As Torrance argues, without the crafting of the 'essential furniture of our knowledge of God' in Israel, the incarnation would have been incomprehensible. To be sure, behind John the Baptist's acclamation of Jesus as the Lamb of God who takes away the sin of the world lies a rich history of images and concepts developed in Israel that make this acclamation comprehensible.

Nevertheless, for the nation as a whole, the incarnation remained incomprehensible, for the vast majority of the Jews rejected their Messiah as he appeared in Jesus. Torrance's discussion make sense only when read in view of the relatively small numbers of Jews who actually believed in Jesus. Yet, problems remain, even in regard to those who followed Jesus. While the first disciples were Jews and thus familiar with the words and concepts that arose in relation to God's self-revelation in Israel, why did they not understand who Jesus was until after the resurrection? Thomas, for example, finally knew Jesus and called him Lord, not because he had been historically and culturally conditioned to know the Messiah, but because he encountered the risen Jesus and put his hand into his wounds. Similarly, the two disciples on the road to Emmaus did not immediately know the risen Lord, even though Jesus explained to them all that was written about him in the Scriptures. They finally knew Jesus only in the breaking of bread. Like the tax collector, Zacchaeus, the Emmaus disciples were transformed by a personal encounter with Jesus, not by their cultural understanding of the images and concepts developed in Israel. Without doubt, the Emmaus disciples would have known Jesus even in the absence of what Torrance describes as the 'essential furniture of the knowledge of God' crafted in Israel. In view of the disciples' enlightenment as the result of their personal encounter with the Risen Lord, the relevance of Torrance's discussion of the mediation of revelation in Israel as a preparation for the coming of Jesus is significantly diminished.

The issue of personal encounter raises further issues, not only in Torrance's discussion of the prehistory of the incarnation in Israel, but also in his theology as a whole. Like Barth, Torrance is, arguably, subject to criticism for his overemphasis on the objective (i.e. divine) aspect of the God-human encounter at the expense of the subjective (i.e. individual or personal) encounter with God. For Torrance, Jesus embodies and enacts the covenanted way of response that God provided to Israel. Jesus is the middle ground who brings sinful humanity into communion with God.
In view of Torrance's assertion that Jesus lived a vicarious life of perfect faith and obedience on behalf of all humanity and died a vicarious death that is efficacious for all, we are left to ponder the role, if any, of the individual believer in redemption. If Jesus offered perfect faith for all, is individual faith important or even relevant? If Jesus offered perfect obedience for all, what is the place, if any, of obedience in the believer's life? As a reformed theologian, Torrance rightly rejects synergism. Nevertheless, he has inadequately addressed the place of personal response in relation to God's self-giving in Jesus. While Torrance's supporters will be quick to point out that the life and death of Jesus Christ are the objective ground that underlies the subjective response, it remains that Torrance's strong emphasis on the objective aspect of God's plan of reconciliation, as it unfolds in Israel and is fully enacted in Christ, invites confusion in regard to the place of the subjective response in redemption.

The inadequacy of Torrance's account of the subjective aspects of the God-human encounter is related to his lack of attention to Pneumatology relative to Christology. Since only by the Spirit can we say 'Jesus is Lord', the role of the Holy Spirit in the God-human encounter merits greater attention in Torrance's work. This is not to suggest that Torrance gives no place to the work of the Spirit, for his entire theology is firmly grounded in the doctrine of the Holy Trinity. By emphasising the objective aspect of the God-human encounter in his Christology, however, and by giving significantly less attention to the role of the Holy Spirit in the mediation of revelation and reconciliation, Torrance has inadequately addressed the subjective aspect of salvation.

Because his emphasis on Christology overshadows his Pneumatology, comparatively little scholarly attention has been paid to Torrance's doctrine of the Holy Spirit as compared to the number of works that have been published on his Christology. Thus, Torrance's doctrine of the Holy Spirit, in general, and his view of the subjective aspects of the God-human encounter, in particular, provide a fertile ground for further scholarly research and development in the field of Torrance's studies.

\section{Acknowledgements Competing interests}

The author declares that he has no financial or personal relationship(s) which may have inappropriately influenced him in writing this article.

\section{References}

Barth, K., 1958, Church dogmatics, vol. 3.1, ed. G. Bromiley \& T. Torrance, T\&T Clark, Edinburgh.

Chung, T., 2011, Thomas Torrance's mediations and revelation, Ashgate, Farnham.

Colyer, E.M., 2001, How to read T.F. Torrance: understanding his Trinitarian \& scientific theology, InterVarsity Press, Downers Grove, IL.

Davis, M.M., 2013, 'Kataphysical inquiry, onto-relationality, and elemental forms in T.F. Torrance's doctrine of the mediation of Jesus Christ', In die Skriflig/In Luce Verbi 47(1), Art. \#100, http://dx.doi.org/10.4102/ids.v47i1.100 
Eugenio, D.O., 2014, Communion with the triune God: the Trinitarian soteriology of T.F. Torrance, Pickwick Publications, Eugene, OR. (Princeton Theological Monograph Series, 204).

Habets, M., 2013, Theology in transposition: a constructive appraisal of T.F. Torrance, Fortress Press, Minneapolis, MN.

Kruger, C.B, 1989, 'Participation in the self-knowledge of God: the nature and means of our knowledge of God in the theology of T.F. Torrance', PhD thesis, Kings College, University of Aberdeen.

McGrath, A.E., 1999, T.F. Torrance: an intellectual biography, T\&T Clark, Edinburgh.

Molnar, P.D., 2009, Thomas F. Torrance: theologian of the Trinity, Ashgate Publishing Company, Burlington, VT.

Purves, A., 2015, Exploring Christology and atonement: conversations with John McLeod Campbell, H.R. Mackintosh and T.F. Torrance, Intervarsity Press, Downers Grove, IL.

Scandrett, J.A., 2006, 'Suffering Servant, wounded Word, troubled Trinity: the passion of God in the theology of T.F. Torrance', PhD thesis, The Caspersen School of Graduate Studies, Drew University.

Torrance, T.F., 1949, 'Universalism or election?' Scottish Journal of Theology 2, 310-318.

Torrance, T.F., 1952, 'Salvation is of the Jews', Evangelical Quarterly 22(3), 164-173.

Torrance, T.F., 1956, 'The Israel of God: Israel and the incarnation', Interpretation 10, 305-320.

Torrance, T.F., 1957, When Christ comes and comes again, Wipf \& Stock Publishers, Eugene, OR.

Torrance, T.F., 1959, The school of faith: the catechisms of the Reformed Church, James Clark \& Co., London.

Torrance, T.F., 1969, Theological science, Oxford University Press, Oxford.
Torrance, T.F., 1970, 'The Problem of Natural Theology in the Thought of Karl Barth' Religious Studies 6, 121-135.

Torrance, T.F., 1971, God and Rationality, Oxford University Press, London.

Torrance, T.F., 1980, The Ground and Grammar of Theology: Consonance Between Theology and Science, T\&T Clark, Edinburgh.

Torrance, T.F., 1981a, Divine and Contingent Order, T\&T Clark, Edinburgh.

Torrance, T.F., 1981b, Christian Theology and Scientific Culture: Comprising the Theological Lectures at the Queen's University, Belfast for 1980, Oxford University Press, New York.

Torrance, T.F., 1982, Reality and Evangelical Theology: The Realism of Christian Revelation, InterVarsity Press, Downers Grove, IL.

Torrance, T.F. 1983, 'The Deposit of Faith', Scottish Journal of Theology 36, 1-28.

Torrance, T.F., 1988, The Trinitarian Faith: The Evangelical Theology of the Ancient Catholic Church, T\&T Clark, London.

Torrance, T.F., 1990, Karl Barth: Biblical and Evangelical Theologian, T\&T Clark, Edinburgh.

Torrance, T.F., 1992, The Mediation of Christ, rev. edn., Helmers \& Howard, Colorado Springs, CO.

Torrance, T.F., 1996a, The Christian Doctrine of God, One Being Three Persons, T\&T Clark, London.

Torrance, T.F., 1996b, Theology in Reconstruction, Wipf \& Stock Publishers, Eugene, OR.

Torrance, T.F., 1996c, Scottish Theology from John Knox to John McLeod Campbell, T\&T Clark, Edinburgh.

Torrance, T.F., 2008, Incarnation: The Person and Life of Christ, ed. R. Walker, InterVarsity Press, Downers Grove, IL. 